International Journal of

Supply Chain and Logistics

(IJSCL)

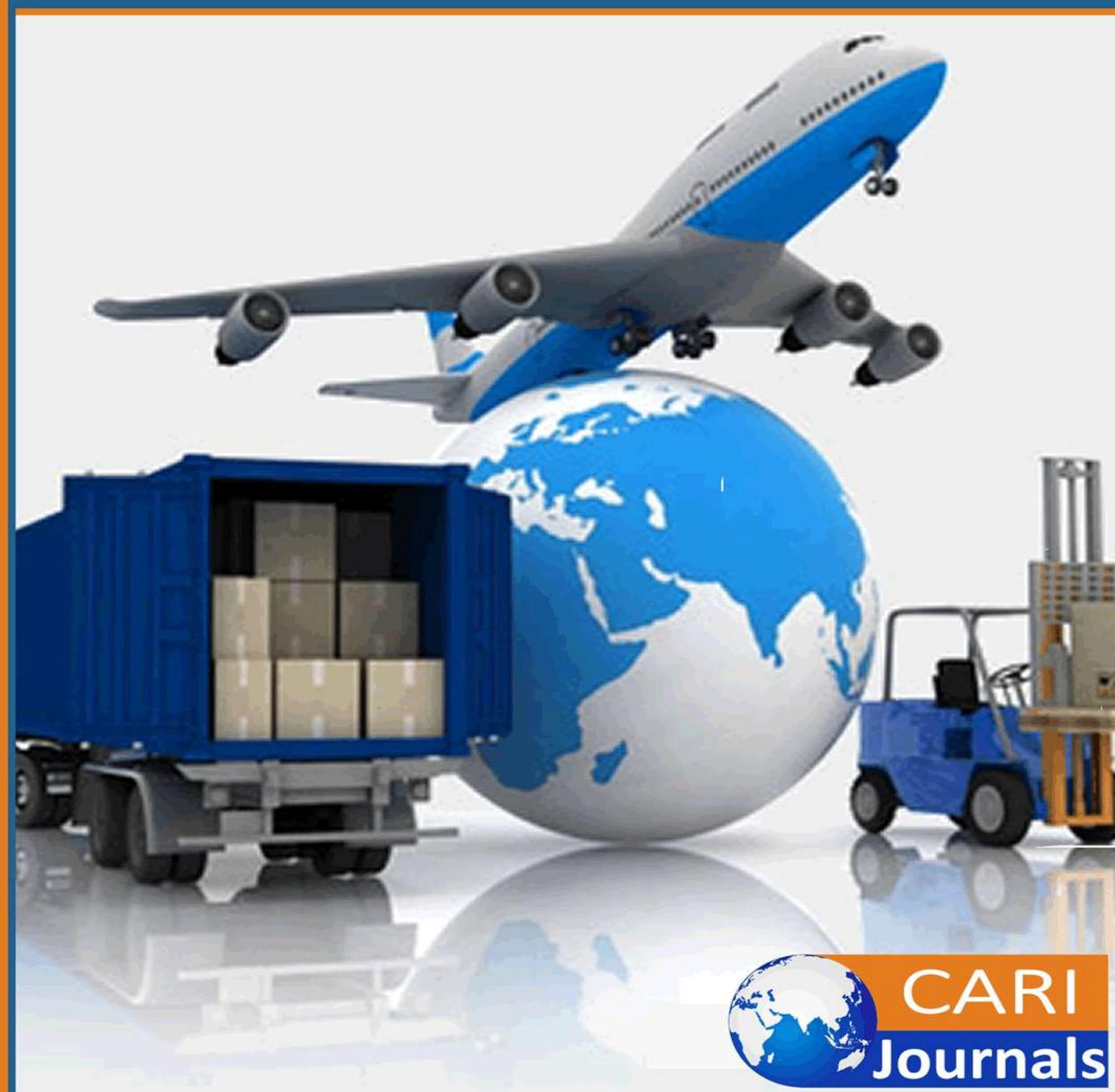




\title{
INFLUENCE OF SUPPLIER EVALUATION CRITERIA ON PERFORMANCE OF METALS AND ALLIED FIRMS IN KENYA
}

\author{
${ }^{1 *}$ Mary Nyambura Kimani \\ College of Human Resource and Development, Jomo Kenyatta University of Agriculture and \\ Technology \\ P. O. Box 62000, 00200 Nairobi, Kenya \\ Corresponding Author email: mkimani58@gmail.com \\ ${ }^{2}$ Dr. Patrick Mwangangi \\ College of Human Resource and Development, Jomo Kenyatta University of Agriculture and \\ Technology \\ P. O. Box 62000, 00200 Nairobi, Kenya
}

\begin{abstract}
Purpose: This study aimed at examining the influence of supplier evaluation on performance of metal and allied firms in Kenya by focusing on supplier's financial capability, supplier's regulatory compliance, supplier's technical capability and supplier's level of human resource competency. The study was guided by Lean Supplier Competence Model, Institutional Theory, Resource Based Theory and Social Exchange Theory.

Methodology: The population target of the study comprised of 213 respondents drawn from managerial, supervisory and junior positions in procurement departments in all 71 metal and allied firms in Kenya. The study adopted a census method where it included all members of the target population. Questionnaires and data collection sheets were used to collect primary and secondary data respectively. The collected data was coded and analyzed qualitatively and quantitatively through Statistical Package for Social Sciences (SPSS) version 21. Data was analyzed using both descriptive and inferential statistics where regression analysis was used to establish the effect of independent variables on the dependent variable. Descriptive and inferential results were presented in form of tables and figures. Pilot study was conducted prior data collection to test reliability and validity of data collection instruments.

Results: The findings of the study revealed that supplier's financial capability, supplier's regulatory compliance, supplier's technical capability and supplier's level of human resource competence have a positive and significant influence on performance of metal and allied firms in Kenya.

Recommendations: The study recommends that metal and allied firms should focus on supplier's financial capability, supplier's regulatory compliance, supplier's technical capability and supplier's level of human resource competence when conducting supplier's evaluation since the practices have a positive and significant influence on performance of metal and allied firms.
\end{abstract}

Key Words: Financial Capability, Regulatory Compliance, Technical Capability, Level Of Human Resource Competence And Performance Of Metal And Allied Firms. 


\section{INTRODUCTION}

In today's business environment, firms are faced with a high competition due to a steady increase in focus of delivering valued and quality products to consumers. Currently, changes in technology and increased quality demand from consumers worsen competition. The ability of organization to constantly offer quality and stand stiff competition depends to a great extent on its accessibility to quality supply of products and services (Aseka, 2010). In attempt of cutting down materials and production costs, organizations are engaging in strategic supplier evaluation activities that aim at acquiring the best suited supplier. According to Gordon (2008), supplier evaluation is a process of evaluating and approving potential suppliers through quantitative and qualitative assessment. Similarly, it is a continuous process applied to existing suppliers within a firm to measure and monitor their supply performance to reduce cost and mitigate risks. For effective and reliable sustainability of supplies, firms should conduct careful selection of suppliers and evaluate them regularly (Sundtoft \& Ellegaard, 2011). The evaluation process provides a firm with a better understanding of the best performing suppliers who can be involved in a supply activity. Arsan (2011) asserts that appropriate supplier selection forms a fundamental strategy that ensures a firm outputs quality products which enhances its competitiveness and maintains its reputation.

Supplier evaluation is a continuous process in purchasing departments and forms a prequalification step in the process of purchasing and in most cases, it involves participation and contributions of other departments (Mungai, 2014). Most supplier evaluation exercise takes the form of five-step processes that determines which supplier to approve. The process involves use of a questionnaire or interview, a site visit, evaluation of various supplier's attributes such as capacity, quality assurance, financials, organization structure and performance. According to argument by Darren (2006), supplier evaluation ought to be identified within the sourcing process since it is a critical purchasing and supply role and should adhere to existing requirements by consumers.In regard to information acquired through the evaluation exercise, a supplier is scored and either gets an approval or disapproval to supply the required materials to the firm. Many firms possess an approved supplier list where they continuously update and add qualified supplier (Hald \& Ellegaard, 2011). In case of rejection, a supplier is generally denied accessibility of a firm's procurement officers. If approved, a supplier can undergo a periodic reevaluation process normally on yearly basis depending on the firm's re-evaluation terms. Jens (2014) notes that it is the role of supply team in a firm including metal and allied firms, to ensure the evaluation process is conducted in the right way following the laid down protocols to acquire the best fit supplier.

For any organization aiming at achieving set goals and objectives, supplier evaluation process should perhaps be the utmost important role of focus in a supply chain function (Omanga, 2017). To perform well, organizations must develop scoring criteria to be used in evaluating and identifying suppliers to be engaged and included in the vendor list. The scoring criteria parameters should be cautiously selected for maximum performance of metal and allied firms. Pearson and Ellram (2013) notes that supply chain manager bears the responsibility of identifying and critically analyzing supplier associated factors to get the best suit supplier who will supply according to stipulated guidelines for better performance of firms. 
Supplier evaluation in Metals and Allied firms is conducted to ensure that supply systems, procedures and practices are followed to achieve the demands of customers. According to Chartered Institute of Procurement and Supply (2013), products that a firm purchases, on average, contributes between $40 \%$ and $60 \%$ of sales from the end products hence influencing the cost and quality of purchased products. Supplier evaluation is conducted to evaluate supplier's capabilities inclusive of finances, technicalities, knowhow and development (Mogikoyo, 2016). For metal and allied firms to perform competitively and maintain their market share, it is important to select reliable suppliers capable of adhering to the firm's supplies requirements and expectations. A firm should aim at acquiring a supplier who is honest, deals fairly with customers and his employees and who has enough and adequate plant facilities (Awino \& Gituro, 2011).

\section{Statement of the Problem}

The performance of metal and allied firms Kenya has been affected by use of obsolete supply chain management practices and technologies with poor state of physical infrastructure, limited research and development, poor institutional framework, and inadequate supply chain evaluation, technical, and procurement skills. Statistics from World Bank show that Kenyan manufacturer's mostly metal and allied firms have registered stagnation and declining profits for the last five years due to a turbulent operating environment (WB, 2014). It is estimated that the sector have lost 70 per cent of their market share in East Africa largely attributed to contingencies arising from among others improper management of supply chain (RoK, 2014). Metal and allied firms in the manufacturing sector in Kenya record dismal performance in terms of profits, market share and customer retention (KAM, 2014). The performance and development of metal and allied firms oscillated between $1 \%$ and $1.5 \%$ per year for a period of 10 years from 2004 to 2014 indicating stagnation. Statistics from KAM (2014) indicates a further drop in performance from $1.5 \%$ by the end of 2014 to $1.2 \%$ in the year ending 2016 . Despite the emphasis laid on supplier evaluation practices, the sector continues to perform dismally.

According to a research by Schiele (2007), extensive and continuous supplier evaluation significantly influences the level of performance of a firm. Similarly, a study by Thairu et al (2012) focused on determinants of supplier evaluation and concluded that financial strength, supplier's location and application of information and technology greatly determined supplier's evaluation. In his study on supply chain management on food and beverage manufacturing firms at Nairobi Stock Exchange, Okello (2014) established that various supplier evaluation methods influenced performance of food and beverage firms. Numerous studies have been done on supplier evaluation but few focused on the influence of supplier evaluation on performance of Metal and allied Firms. This study aims at filling the existing knowledge gap by assessing the influence of supplier evaluation on performance of metal and allied firms in Kenya.

\section{Reserch Objectives}

i. To examine the influence of supplier's financial capability on performance of metal and allied firms in Kenya.

ii. To determine the influence of supplier's regulatory compliance on performance of metal and allied firms in Kenya. 
iii. To find out the influence of supplier's technical capability on performance of metal and allied firms in Kenya.

iv. To establish the influence of supplier's level of human resource competency on performance of metal and allied firms in Kenya.

\section{LITERATURE REVIEW}

\section{Theoretical Review}

\section{Lean Supplier Competence Model}

The model developed by Marks (2007) aims at evaluating a supplier's capabilities against the five categories that supports the Lean techniques of Kaizen - continuous improvement. The model explains the interactions between organizations based on five competency areas where varying performance degree exist that determines the achievement of lean organizational operations. The five categories and "specific behaviors" of supplier to be evaluated comprise of quality characterized by Part Specification, reliability and consistency, Corrective Action Process and Preventative and Predictive Maintenance; Delivery characterized by Delivery performance, Lead Time and Location of Suppliers; Financials characterized by Supplier's Cost of Quality, Buyer's Order Quantity Requirements, Buyer's Cost of Quality and Supplier's Infrastructure and stability; Operational Excellence characterized by Vision and Mission, Supplier's Company Culture benchmark and Supplier's Commitment to Waste Elimination; General Performance Measures characterized by Training, support services, Design, reporting and capacity (Mark, 2007).

According to Marks(2007), each category is broken down into specific behaviors or determinants of interaction between a company and a supplier. The behaviors are rated on a scale of between 1 and 5 depending on the degree of leanness where 1="Less Lean" to 5="More Lean". The rating scale allows an organization to determine business placement in regard to common strategic goals and values. Singer (2007), notes that a company's business philosophy and supply base interrelates resulting to a natural reduction of cost to the supply chain and to the final customer. This theory is of relevant in supplier evaluation process since it advocates for competence in the supplier side. Similarly, one of the key focus of the model is financial capability of supplier. The organization intending to acquire a supplier need to know the supplier's financial competence in terms of financing methods, assets owned, cash flow management and debts owed. With this information, the organization will be able to gauge the fitness of the supplier and whether the supplier will be capable of delivering the required goods or services without experiencing financial problems.

\section{Institutional Theory}

The institutional theory was developed by Scott in 2004 . The theory stipulates that institutions comprise of regulative elements comprising of regulations, normative and cultural cognitive and must be adhered to in the process of executing set activities. The regulatory elements emphasizes on application of laws, rules and sanctions as enforcement mechanism that forms compliance base. The normative aspect defines how things should be done in the preferred and desirable manner. 
The cultural-cognitive aspect focuses on understanding of common beliefs shared by involved parties. In this context, organization and suppliers form the parties involved in the supply system. The theory defines organizations as having own set rules and regulations that governs how activities are carried out. Organizations expect total adherence of the set rules by any party aiming at transacting business with them. On the other hand, $\operatorname{Scott}(2004)$ notes that there exist outside rules and regulations that governs how businesses are transacted between parties. The rules outline procedures to be followed and the consequences that follows when one deviates from the laid down rules.

In organization-supplier relationships, compliance to rules and regulations is of paramount importance. The institutional theory contributes to supplier evaluation process by focusing on supplier regulatory compliance. A reliable supplier conforms to regulations defined by regulating bodies in the area of operation. Compliance to supply rules and regulations determines whether an organization will contract the supplier. The theory is adopted in this study to find the influence of supplier's regulatory compliance on performance of metal and allied firms.

\section{Resource Based Theory}

According to Corner \& Prahalad (2007), resource based theory stipulates that for a firm to have a competitive advantage over another, it must be in possession of core resources. In the resource based model, resources that a firm possess contributes majorly to the overall firms' performance. Resources in a firm are categorized into tangible and intangible. Tangible resources define the physical goods characterized by the ability to touch while the intangible resources do not have a physical nature and includes services. According to Barney (1991), resources possessed by organizations, either tangible or intangible, differ from one firm to the other. RBT underpins the independent variables of the study which are supplier's financial capability and technical capability. A firm that possesses strong financial grounds competes and performs better than its competitors. Similarly, a firm that has advanced technologically contributes significantly to reduction in lead which helps a firm to operate efficiently and achieve overall performance. A good performance is an indicator of sustainability and sustainable suppliers ensures there is continuous supplies that enhances continuous production and supply of goods and services by a firm to consumers thus meeting consumers demand (Barney, 1991).

\section{Social Exchange Theory}

Social Exchange Theory spearheaded by (Emerson, 1976), propose that social behaviors results from an exchange process. The theory comprises of both sociological and social psychological perspective that attempts to give an explanation of both stability and social change as a resultant of negotiated exchanges amongst parties. According to Fiske (1992), existing human relationships are as a result of subjective cost benefit analysis and comparison of available alternatives. In social exchange perspective, individuals and organizations analyze the worthiness of a relationship by subtracting the relationship's costs from the reward the relationship provides. If the resultant number is positive, the relationship is positive while negative number indicates negative relationship. According to Emerson, (1976) worthiness of a relationship determines continuation or termination of a relationship. When a relationship is positive, it is expected to endure while negative relationship is bound to terminate. 
Other principles that govern social exchange theory include cooperation, satisfaction, trust and relational virtue that dominates written contracts, develops over time and overtakes the governance of relationship. The theory establishes relationship that exists between firms and suppliers. When acquiring suppliers, firms look at the benefits suppliers will bring to the firm. A firm takes the responsibility of empowering a supplier through offering contracts, training and motivational development. As a result, a supplier reciprocates by offering discounts and goods on credit to the firm. Additionally, the supplier offers product innovation, reduced lead time, reduced supply risk, increased product safety and competitive pricing for the buyer. Both parties develop a mutual benefit relationship that ensures continuity of partnership. Similarly, supplier's level of competency as depicted by past performance determines its competitive status against other competitors. The theory is adopted in this study to explain the effects of supplier's level of human resource competency on performance of metals and allied firms in Kenya.

\section{Conceptual Framework}

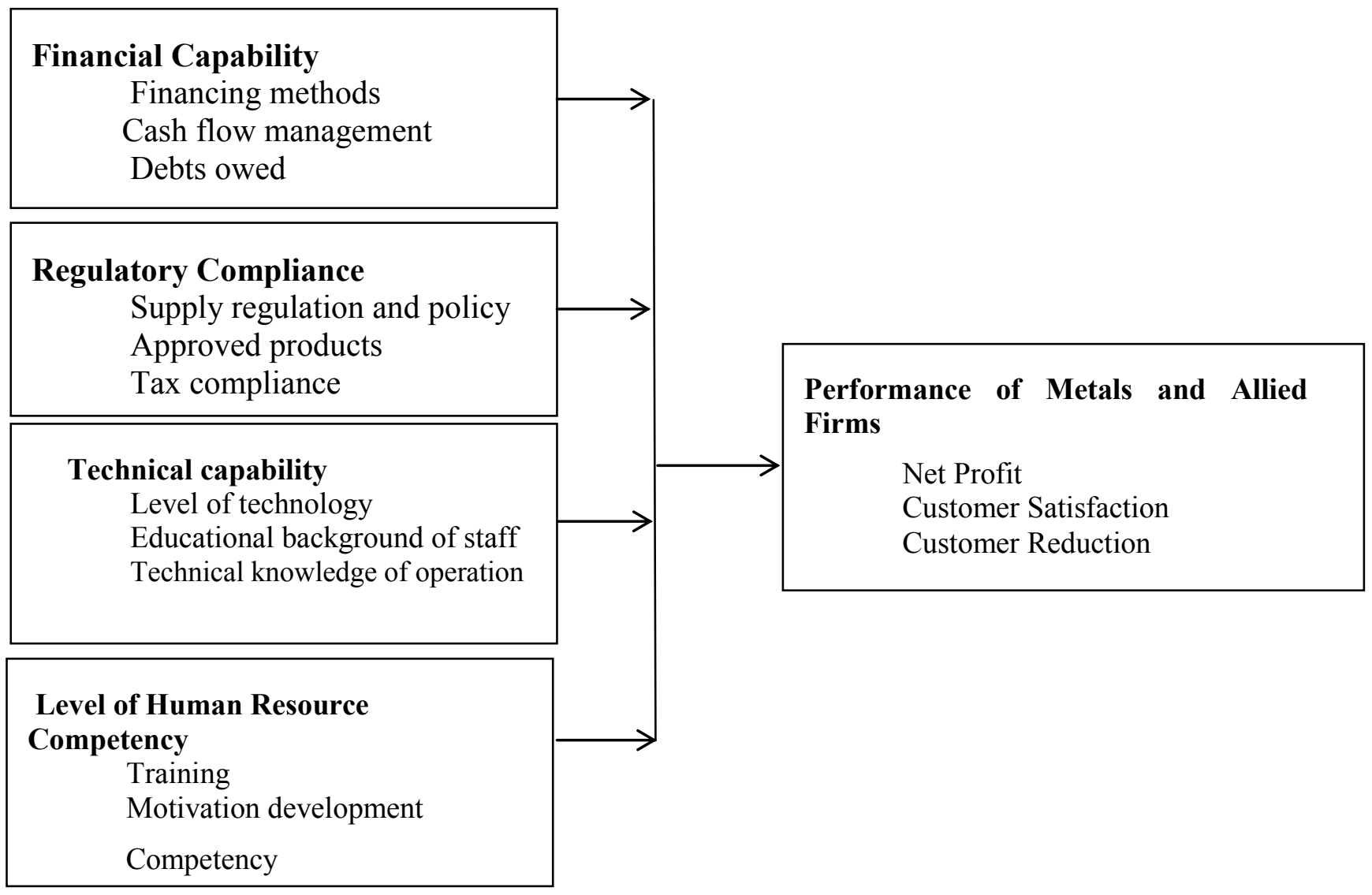

Independent variables

Dependent Variable

Figure 1: Conceptual Framework 


\section{Supplier's Financial Capability}

According to Jack (2011), financial capability of a supplier is one of the key factors that firms use to determine the best fit supplier. Financial health of a supplier boost a firm's production confidence in that a firm is assured of continuous supply of goods needed in the production process. Similarly, a financially stable supplier is committed to performance and aims at contributing to the general performance of the firm. Many firms aim at acquiring suppliers who will contribute to reduction in cost of production of a firm and at the same time play a role in ensuring customers demand are met. A supplier meets the terms set by a firm by availing goods in their right specification in terms of quality, quantity, cost and at the required time. Firms on the other hand ensure continuous production and delivery to customers hence enhancing continuous production. When evaluating supplier's financial capability, different firms evaluate different components of finance endowed by a supplier. Financial components are determined by the requirements of the firm. Most firms rely on financial statements provided by a supplier during evaluation. The statements mostly evaluated include and not limited to balance sheets, interim and audited financial statements and financial notes from auditors (Vonderembse \& Tracy, 2009).

\section{Supplier's Regulatory Compliance}

Regulatory compliance is a process of conforming to set rules, guidelines and regulations that govern business operations. The regulations are normally set by a government agency or an appointed regulatory body of applicable industry and are expected to be followed in the course of transacting business. Regulatory bodies vary differently in respect to industries under operations. Supplier regulatory compliance comprises of confirming to regulations that governs a country's supply system. Businesses and suppliers are expected to adhere to set rules and any violation of the rules is met with tough consequences. In Kenya, the government enacted the Public Procurement and Disposal Act (PPDA) in 2005 that governs the supplier ethics in public procurement and disposal. The rules and regulations of the acts are governed and implemented by Public Procurement Oversight Authority (PPOA).

\section{Supplier's Technical Capability}

Isobe et al (2008) defines technology in business context as any form development that a firm integrates in its operation to ease activities in an out of the firm. Similarly, businesses welcome new technologies that aim at reducing the cost of production. In business field, technology is associated with machines and technical operation knowledge that simplify activities in a firm while at the same time contribution to performance. Due to continuous changes in technology, flexibility to change and adoption is a trait that firms incorporates. A firm that incorporates technology in its operations stands a better position of advancement than others with minimum technological endowment (Simons, Brandow \& Chank, 2007). When sourcing for suppliers, firms emphasizes on technological advancement of a potential supplier. Efficient supplier aims at enabling a firm in cutting production cost by offering a firm goods and services that match with firm's needs. Consequently, technological advancement of a supplier determines the efficiency of delivering supplies to a firm. 


\section{Supplier's Level of Human Resource Competency}

Krause (2012) defines supplier's competency as the ability of supplier to supply efficiently. To achieve competence, suppliers need to have pooled resources both technical and human that enable the supplier to stand competitive environment in the market place. One of the key indicators of competency is human resource practices that contribute to supplier's performance. Human resource management is often considered as an important part of every successful supplier (Lee et al, 2009). Human resource experts have collectively held the idea that no firm can be better than its constituent elements, its employees (Nwabueze, 2008). Drawing from this assertion, it is clear that quality of supplier's human resource management policies can be used as one of the attributes that can influence supplier selection (Meegan et al., 2010). According to CIPS (2010), the main aspects of supplier human resources that needs close attention include the degree with which the supplier's HR policies are revised in favor of employees; qualifications, skills and experience of the management staff; adequacy of staff; employees' turnover; presence of training programs and staff compensation and satisfaction. Employees are one of the most valuable assets of the firm and those of its suppliers. Waithaka and Waiganjo (2015) assert that firms pays attention to suppliers whose human resource is well established and cares the needs of employees through motivation and training.

\section{RESEARCH METHODOLOGY}

The study adopted descriptive survey design and targetd all 71 metal and allied firms in Kenya. and targeted 1 manager, 1 supervisor and 1 junior staff in each firm totalling to 213 respondents. The study used both primary and secondary data where primary data was collected using questionnaires while secondary data was collected through dat collection sheets. SPSS software was used for the analysis and results of the analysis presented by use of tables and figures. Inferential statistics was used to establish the association between independent variables and dependent variable. Performance of metal and allied firms was regressed against four variables of suppier evaluation criteria (fiancial capablity, regulatory complince, technical capabilty and level of human resource competence). The regression model is as follows;

$$
Y=a+\beta_{1} X_{1}+\beta_{2} X_{2}+\beta_{3} X_{3}+\beta_{4} X_{4}+\varepsilon
$$

Where; Y: Performance of metal and allied firms, $\mathrm{X}_{1}$ : fiancial capability, $\mathrm{X}_{2}$ : regulatory complince, $\mathrm{X}_{3}$ : technical capability, $\mathrm{X}_{4}$ : level of human resource competence, $\alpha=$ regression coefficient, $\beta_{1}, \beta_{2}, \beta_{3}$ and $\beta_{4}=$ coefficients of various independent variables and $\varepsilon=$ error term 


\section{RESULTS}

The study administered 213 questionnaires and 147 questionnaires were filled and returned. This represented a response rate of $69 \%$.

\section{Descriptive Findings and Analysis}

\section{Supplier Financial Capability}

The study sought to examine the influence of supplier's financial capability on performance of metal and allied firms in Kenya. Respondents were requested to indicate the level of agreement with statements on supplier's financial capability on performance using a scale of 1 to 5 where 5= Strongly Agree, 4= Agree, 3= Uncertain, 2= Disagree and 1= Strongly Disagree. The findings of the study are presented in table 1 below. The result revealed that respondents agreed to the statements that ssuppliers' balance sheets is evaluated before engaging in business with them (mean= 4.09 and standard deviation=0.92), that Suppliers' creditors are evaluated before engaging in business with them (mean $=4.63$ and standard deviation $=0.78$ ), that suppliers' cash flow management is evaluated before engaging in business with them (mean $=4.85$ and standard deviation=0.36), that Supplier's financial capability is concentrated before engaging in business with them (mean $=4.06$ and standard deviation=0.94) and that supplier financial capability is conducted by a team of credible professional with procurement /finance background (mean= 4.00 and standard deviation=0.98). However, respondents were indifferent on whether debts owned by suppliers are evaluated before engaging in business with them (mean= 3.26 and standard deviation=1.15) and on whether assets owned by suppliers are evaluated to determine their financial capability (mean= 3.07 and standard deviation=1.26). On average, respondents agreed with the statements on supplier's financial capability as shown by average mean of 3.99 and average standard deviation of 0.91. This implies that metal and allied firms focus on supplier's financial capability during evaluation. The results of the study are consistent with Jack (2011) findings that financial capability of a supplier is one of the key factors that firms use to determine the best fit supplier. 
International Journal of Supply Chain and Logistics

ISSN 2520-3983 (Online)

Vol. 2, Issue 1, pp $93-117,2018$

www.carijournals.org

Table 1: Descriptive Statistics on Supplier's Financial Capability

\begin{tabular}{|c|c|c|}
\hline Statement & Mean & Std Dev \\
\hline $\begin{array}{l}\text { Suppliers' balance sheets is evaluated before engaging in } \\
\text { business with them }\end{array}$ & 4.09 & 0.92 \\
\hline $\begin{array}{l}\text { Suppliers' creditors are evaluated before engaging in } \\
\text { business with them }\end{array}$ & 4.63 & 0.78 \\
\hline $\begin{array}{l}\text { Suppliers' cash flow management is evaluated before } \\
\text { engaging in business with them. }\end{array}$ & 4.85 & 0.36 \\
\hline $\begin{array}{l}\text { Debts owned by suppliers are evaluated before engaging } \\
\text { in business with them. }\end{array}$ & 3.26 & 1.15 \\
\hline $\begin{array}{l}\text { Assets owned by suppliers are evaluated to determine } \\
\text { their financial capability }\end{array}$ & 3.07 & 1.26 \\
\hline $\begin{array}{l}\text { Supplier's financial capability is concentrated before } \\
\text { engaging in business with them. }\end{array}$ & 4.06 & 0.94 \\
\hline $\begin{array}{l}\text { The supplier financial capability is conducted by a team } \\
\text { of credible professional with procurement /finance } \\
\text { background }\end{array}$ & 4.00 & 0.98 \\
\hline Average & 3.99 & 0.91 \\
\hline
\end{tabular}

\section{Supplier's Regulatory Compliance}

The second objective of the study sought to determine the influence of supplier's regulatory compliance on performance of metal and allied firms in Kenya. Respondents were requested to indicate the level of agreement with statements on supplier's regulatory compliance on performance using a scale of 1 to 5 where $5=$ Strongly Agree, 4= Agree, 3= Uncertain, 2= Disagree and $1=$ Strongly Disagree. The findings of the study as presented in table 2 revealed that respondents agreed with statements that suppliers' compliance on Supply regulations is evaluated (mean=3.79 and standard deviation=1.35), that suppliers' policy compliance is evaluated (mean $=3.57$ and standard deviation $=1.38$ ), that an assessment of suppliers' products is conducted prior engaging in business with them (mean $=4.32$ and standard deviation $=0.72$ ), that supplier's certifications with regulatory bodies is evaluated(mean $=4.68$ and standard deviation $=0.63$ ), that regulatory compliance of suppliers is considered crucial before business engagements (mean=3.53 and standard deviation=1.12). However, respondents were indifferent on whether suppliers are provided with company's set supply regulations (mean=3.38 and standard deviation=1.51) and on whether tax compliance of suppliers is evaluated (mean=3.44 and standard deviation=1.35). 
On average, respondents agreed with statements on supplier's regulatory compliance as shown by average mean of 3.82 and average standard deviation of 1.22. The results concurs with Tahriri et al (2008) observations that firms that perform well in their areas of operations have a clearly defined set of rules that governs their relationship and that of the supplier.

Table 2: Descriptive Statistics on Supplier's Regulatory Compliance

\begin{tabular}{lll}
\hline Statement & Mean & Std Dev \\
\hline $\begin{array}{l}\text { Suppliers' compliance on Supply regulations is evaluated } \\
\text { Suppliers' policy compliance is evaluated }\end{array}$ & 3.79 & 1.35 \\
$\begin{array}{l}\text { An assessment of suppliers' products is conducted prior } \\
\text { engaging in business with them }\end{array}$ & 4.32 & 0.72 \\
$\begin{array}{l}\text { Supplier's certifications with regulatory bodies is } \\
\text { evaluated }\end{array}$ & 4.68 & 0.63 \\
$\begin{array}{l}\text { Suppliers are provided with company's set supply } \\
\text { regulations }\end{array}$ & 3.38 & 1.51 \\
$\begin{array}{l}\text { Tax compliance of suppliers is evaluated } \\
\text { Regulatory compliance of suppliers is considered crucial } \\
\text { before business engagements. }\end{array}$ & 3.53 & 1.35 \\
\begin{tabular}{l} 
Average \\
\hline
\end{tabular} & $\mathbf{3 . 8 2}$ & 1.12 \\
\hline
\end{tabular}

\section{Supplier's Technical Capability}

The third objective of the study sought to find out the influence of supplier's technical capability on performance of metal and allied firms in Kenya. Respondents were requested to indicate the level of agreement with statements on supplier's technical capability on performance using a scale of 1 to 5 where 5= Strongly Agree, 4= Agree, 3= Uncertain, 2= Disagree and 1= Strongly Disagree. The results are presented in table 3. According to the results, respondents agreed with the statements that supplier's technological advancement is evaluated (mean=3.53 and standard deviation=1.39), that Supplier's digitalization in supply process is evaluated (mean=3.77 and standard deviation=1.34), that Suppliers advancement in technology is highly advocated (mean=4.32 and standard deviation=1.01), that Supplier's staffs educational background is evaluated (mean=4.43 and standard deviation=1.04), that Supplier's staffs educational background is a key factor in evaluation process (mean=4.45 and standard deviation=1.12), and that Technical knowledge of supply operation amongst suppliers is evaluated (mean=3.66 and standard deviation=1.31). 
However, respondents were uncertain on whether Suppliers level of computer knowledge is assessed (mean=3.31 and standard deviation=1.22). On average, respondents agreed with the statements on supplier's technical capability as shown by average mean of 3.92 and average standard deviation of 1.2. The results are consistent with Simons, Brandow and Chank (2007) findings that a firm that incorporates technology in its operations stands a better position of advancement than others with minimum technological endowment.

Table 3: Descriptive Statistics on Supplier's Technical Capability

\begin{tabular}{llll}
\hline Statement & Mean & Std Dev \\
\hline $\begin{array}{l}\text { Supplier's technological advancement is } \\
\text { evaluated }\end{array}$ & 3.53 & 1.39 \\
$\begin{array}{l}\text { Supplier's digitalization in supply process is } \\
\text { evaluated }\end{array}$ & 3.77 & 1.34 \\
$\begin{array}{l}\text { Suppliers advancement in technology is highly } \\
\text { advocated }\end{array}$ & 4.32 & 1.01 \\
$\begin{array}{l}\text { Supplier's staffs educational background is } \\
\text { evaluated }\end{array}$ & 4.43 & 1.04 \\
$\begin{array}{l}\text { Supplier's staffs educational background is a } \\
\text { key factor in evaluation process }\end{array}$ & & 1.45 \\
$\begin{array}{l}\text { Suppliers level of computer knowledge is } \\
\text { assessed }\end{array}$ & 3.31 & 1.22 \\
$\begin{array}{l}\text { Technical knowledge of supply operation } \\
\text { amongst suppliers is evaluated }\end{array}$ & & $\mathbf{3 . 9 2}$ & $\mathbf{1 . 2}$ \\
Average
\end{tabular}

\section{Supplier's Level of Human Resource Competence}

The fourth objective of the study sought to establish the influence of supplier's level of human resource competency on performance of metal and allied firms in Kenya. Respondents were requested to indicate the level of agreement with statements on supplier's level of human resource competence on performance using a scale of 1 to 5 where 5= Strongly Agree, 4= Agree, $3=$ Uncertain, 2= Disagree and 1= Strongly Disagree. The results as presented in table 4.5 revealed that respondents agreed with the statements that the extent to which supplier offers one on one training to employees is evaluated (mean=3.58 and standard deviation $=1.19$ ), that The extent to which supplier values employees training is evaluated (mean=4.62 and standard deviation $=0.78$, that The extent to which supplier invests resources in employees training is 
evaluated (mean=4.68 and standard deviation $=0.43$ ), that Supplier's development initiatives to employees is evaluated (mean=4.55 and standard deviation=0.52), that Suppliers competency levels is evaluated (mean=4.43 and standard deviation= 0.72) and that supplier's level of experience in supply operations is evaluated (mean=3.89 and standard deviation= 1.23). Respondents were however indifferent on whether supplier's motivational practices to employees is evaluated(mean=3.33 and standard deviation=1.69). On average, respondents agreed with the statements on supplier's level of human competence as shown by average mean 4.15 and average standard deviation of 0.94 . The findings concurs with Waithaka and Waiganjo (2015) affirmations that firms pays attention to suppliers whose human resource is well established and cares the needs of employees through motivation and training.

Table 4: Descriptive Statistics on Supplier's Level of Human Competence

\begin{tabular}{|c|c|c|}
\hline Statement & Mean & Std Dev \\
\hline $\begin{array}{l}\text { The extent to which supplier offers one on one training to } \\
\text { employees is evaluated }\end{array}$ & 3.58 & 1.19 \\
\hline $\begin{array}{l}\text { The extent to which supplier values employees training is } \\
\text { evaluated }\end{array}$ & 4.62 & 0.78 \\
\hline $\begin{array}{l}\text { The extent to which supplier invests resources in } \\
\text { employees training is evaluated }\end{array}$ & 4.68 & 0.43 \\
\hline $\begin{array}{l}\text { Supplier's development initiatives to employees is } \\
\text { evaluated }\end{array}$ & 4.55 & 0.52 \\
\hline $\begin{array}{l}\text { Supplier's motivational practices to employees is } \\
\text { evaluated }\end{array}$ & 3.33 & 1.69 \\
\hline Suppliers competency levels is evaluated & 4.43 & 0.72 \\
\hline $\begin{array}{l}\text { Supplier's level of experience in supply operations is } \\
\text { evaluated }\end{array}$ & 3.89 & 1.23 \\
\hline Average & 4.15 & 0.94 \\
\hline
\end{tabular}

\section{Performance of Metal and Allied Firms}

The study sought to establish the performance of metal and allied firms characterized by net profits, customer satisfaction and cost reduction as a result of undertaking supplier evaluation exercise. 
International Journal of Supply Chain and Logistics

ISSN 2520-3983 (Online)

Vol. 2, Issue 1, pp $93-117,2018$

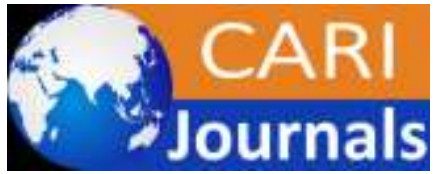

Www.carijournals.org

\section{Net Profits}

The study requested the respondents to indicate the extent to which supplier evaluation contributed to firm's performance in respect to changes in net profits between 2013 and 2017. The results of the findings are shown in table 5 below. In 2013, majority $45 \%$ of respondents indicated a net profit of below Ksh.50million while 30\% indicated a net profit of between Ksh.51million and Ksh.100 million with only $25 \%$ indicating a net profit of $25 \%$. In $2014,35 \%$ of respondents indicated a net profit of below Ksh.100million while 30\% indicated a net profit of between Ksh.101million and Ksh.200million. Additionally, 15.7\% of respondents indicated a net profit of below Ksh.50 million in 2015 with 22.9\% recording a net profit of between Ksh. 51million and Ksh. 200Million while 38.5\% indicated a net profit of above Ksh 200 million. The results further indicated that $10 \%$ of respondents recorded a net profit of less than $10 \%$ in 2016 , $22.9 \%$ and $25 \%$ of respondents recorded a net profit of between Ksh51million and ksh.100 million and between ksh 101 million and ksh.200 million respectively with majority 42.1\% recording a net profit of above Ksh.200 million. In 2017, majority of respondents $48.3 \%$ indicated a net profit of above Ksh.200million with $21.8 \%$ recording a net profit of between Ksh.101 million and Ksh.200million and 20.8\% indicating a net profit of between Ksh 51million and Ksh 100million. Only $9.1 \%$ of respondents recorded a net profit of below Ksh. 50million in 2017. The study findings reveal varying changes in net profits amongst metal and allied firms between 2013 and 2017.

\section{Table 5: Changes in Net Profits}

\begin{tabular}{|c|c|c|c|c|c|c|c|}
\hline & $\begin{array}{l}\text { Below } \\
\text { Ksh.50 } \\
\text { million }\end{array}$ & $\begin{array}{l}\text { Between } \\
51 \text { million } \\
\text { Ksh.100million }\end{array}$ & $\begin{array}{r}\text { Ksh. } \\
-\end{array}$ & $\begin{array}{l}\text { Between } \\
\text { 101million } \\
\text { Ksh.200million }\end{array}$ & $\begin{array}{r}\text { Ksh. } \\
-\end{array}$ & $\begin{array}{l}\text { Above } \\
\text { Ksh. } 200 \\
\text { million }\end{array}$ & $\begin{array}{l}\text { Tota } \\
\text { l }\end{array}$ \\
\hline \multicolumn{8}{|l|}{ NET } \\
\hline PROFIT & & & & & & & 100 \\
\hline 2013 & $45.0 \%$ & $30.0 \%$ & & $25.0 \%$ & & $0.0 \%$ & $\%$ \\
\hline \multicolumn{8}{|l|}{ NET } \\
\hline PROFIT & & & & & & & 100 \\
\hline 2014 & $35.0 \%$ & $35.0 \%$ & & $30.0 \%$ & & $0.0 \%$ & $\%$ \\
\hline \multicolumn{8}{|l|}{ NET } \\
\hline PROFIT & & & & & & & 100 \\
\hline 2015 & $15.7 \%$ & $22.9 \%$ & & $22.9 \%$ & & $38.5 \%$ & $\%$ \\
\hline \multicolumn{8}{|l|}{ NET } \\
\hline PROFIT & & & & & & & 100 \\
\hline 2016 & $10.0 \%$ & $22.9 \%$ & & $25.0 \%$ & & $42.1 \%$ & $\%$ \\
\hline \multicolumn{8}{|l|}{ NET } \\
\hline PROFIT & & & & & & & 100 \\
\hline 2017 & $9.1 \%$ & $20.8 \%$ & & $21.8 \%$ & & $48.3 \%$ & $\%$ \\
\hline
\end{tabular}


International Journal of Supply Chain and Logistics

ISSN 2520-3983 (Online)

Vol. 2, Issue 1, pp 93 - 117, 2018

\section{Customer Satisfaction}

The study also requested the respondents to indicate the extent to which supplier evaluation contributed to firm's performance in respect to customer satisfaction as indicated by customer satisfaction surveys conducted between 2013 and 2017. The results of the findings are shown in table 6 below. According to the results, majority of respondents 30\% in 2013 indicated a customer satisfaction margin of below $60 \%$ while $25.7 \%$ indicated a margin of between $61 \%$ and $90 \%$ and only $14.3 \%$ indicated a margin of over $90 \%$. In $2014,26.7 \%$ of respondents indicated customer satisfaction margin of below 30\%, 45\% indicated a margin of between $31 \%$ and $60 \%$, $8.3 \%$ indicated a margin of between $61 \%$ and $90 \%$ and $20 \%$ indicated a margin of over $90 \%$. In $2015,24 \%$ indicated a margin of below $30 \%$ with $43.7 \%$ indicating a margin of between $31 \%$ and $60 \%$ while $32.3 \%$ indicated a margin of between $61 \%$ and $90 \%$. In $2016,32.3 \%$ of respondents indicated a margin of less than $60 \%, 24 \%$ indicated a margin of between $61 \%$ and $90 \%$ and only $11.4 \%$ indicated a margin of above $90 \%$. Majority of respondents $43.3 \%$ in 2017 indicated a margin of between $31 \%$ and $60 \%, 30.7 \%$ indicated a margin of below $30 \%$ and only $26 \%$ indicated a margin of between $61 \%$ and $90 \%$. The result implies that majority of metal and allied firms had recorded varying customer satisfaction margins between 2013 and 2017.

Table 6: Changes in Customer Satisfaction Margins

\begin{tabular}{llllll}
\hline & $\mathbf{0 \% - 3 0 \%}$ & $\mathbf{3 1 \% - 6 0 \%}$ & $\mathbf{6 1 \% - 9 0 \%}$ & Over 90 \% & Total \\
\hline Customer Satisfaction 2013 & $30.0 \%$ & $30.0 \%$ & $25.7 \%$ & $14.3 \%$ & $100 \%$ \\
Customer Satisfaction 2014 & $26.7 \%$ & $45.0 \%$ & $8.3 \%$ & $20.0 \%$ & $100 \%$ \\
Customer Satisfaction 2015 & $24.0 \%$ & $43.7 \%$ & $32.3 \%$ & $0.0 \%$ & $100 \%$ \\
Customer Satisfaction 2016 & $32.3 \%$ & $32.3 \%$ & $24.0 \%$ & $11.4 \%$ & $100 \%$ \\
Customer Satisfaction 2017 & $30.7 \%$ & $43.3 \%$ & $26.0 \%$ & $0.0 \%$ & $100 \%$ \\
\hline
\end{tabular}

\section{Cost Reduction}

The study further requested the respondents to indicate the extent to which supplier evaluation contributed to firm's performance in respect to cost reduction between 2013 and 2017. The results of the findings as shown in table 7 revealed that $10 \%$ of respondents in 2013 indicated a cost reduction of below Ksh 5million, $27.1 \%$ indicated a reduction of between ksh.5million and ksh 10million, 29.7\% indicated a reduction of between Ksh 11 million and Ksh 15 million while $33.7 \%$ indicated a cost reduction of above Ksh 15million. In 2014 and 2015, majority of respondents, 55\% indicated a cost reduction of below Ksh 5million while 45\% indicated a cost reduction of between Ksh 5million and Ksh 10million. 29\% of respondents in 2016 indicated a cost reduction of between Ksh 5million and 10 million, 36\% indicated a cost reduction of between Ksh 11 million and Ksh 15 million while 35\% indicated a cost reduction of above Ksh15 million. 
In 2017, majority of respondents $39.8 \%$ indicated a cost reduction of between Ksh 5 million and Ksh 10million, 34.2 indicated a cost reduction of above Ksh 15 million while only $26 \%$ indicated accost reduction of between Ksh 11 million and Ksh 15 million. The results imply that most of metal and allied firms gained achieved a cost reduction of between Ksh 5million and Ksh 10million between 2013 and 2017.

Table 7: Cost Reduction

\begin{tabular}{llllll}
\hline & $\begin{array}{l}\text { Below Ksh. 5 } \\
\text { million }\end{array}$ & $\begin{array}{l}\text { Between } \\
\text { Ksh.5 -Ksh.10 } \\
\text { million }\end{array}$ & $\begin{array}{l}\text { Between } \\
\text { Ksh.11- Ksh.15 } \\
\text { million }\end{array}$ & $\begin{array}{l}\text { Above Ksh. 15 } \\
\text { million }\end{array}$ & Total \\
\hline $\begin{array}{l}\text { Cost } \\
\text { Reduction2013 }\end{array}$ & $10.0 \%$ & $27.1 \%$ & $29.2 \%$ & $33.7 \%$ & $100 \%$ \\
$\begin{array}{l}\text { Cost } \\
\text { Reduction2014 }\end{array}$ & $55.0 \%$ & $45.0 \%$ & $0.0 \%$ & $0.0 \%$ & $100 \%$ \\
$\begin{array}{l}\text { Cost } \\
\text { Reduction2015 }\end{array}$ & $55.0 \%$ & $45.0 \%$ & $0.0 \%$ & $0.0 \%$ & $100 \%$ \\
$\begin{array}{l}\text { Cost } \\
\text { Reduction2016 }\end{array}$ & $0.0 \%$ & $29.0 \%$ & $36.0 \%$ & $35.0 \%$ & $100 \%$ \\
$\begin{array}{l}\text { Cost } \\
\text { Reduction2017 }\end{array}$ & $0.0 \%$ & $39.8 \%$ & & & $100 \%$ \\
\hline
\end{tabular}

\section{Inferential Statistics}

\section{Correlation Results}

The study sought to establish the relationship between independent variables (Supplier's Financial Capability, Regulatory Compliance, Technical Capability and Level of Human Resource Competence) and dependent variable (performance). Similarly, a correlation coefficient matrix to establish relationship between independent variables themselves is also indicated. The results are as shown in table 8 . The results of the correlation analysis indicates that the correlation between supplier's financial capability and performance of metal and allied firms is 0.521 and a p-value of 0.000 . This means that the correlation is positive and significant implying that increase in practices on supplier's financial capability leads to increase in performance of metal and allied firms. The results are consistent with Vorster (2010) findings in her study on determinants of supplier evaluation in Pakistan Telecom industry who revealed there high correlation between the financial capacity of supplier and ability of supplier to deliver which in turn enhances firm's performance. 
The results of correlation analysis also indicate that the correlation between supplier's regulatory compliance and performance of metal and allied firms is 0.353 and a p-value of 0.007 . This means that the correlation is positive and significant implying that increase in practices on supplier's regulatory compliance will lead to increase in performance of metal and allied firms. The findings concurs with Mungai (2014) findings which revealed that the criterion used during the evaluation and selection of suppliers determines the comprehensive suitability of the right suppliers who can help the purchasing firm achieve competitive advantage

The results of correlation analysis further indicate that the correlation between supplier's technical capability and performance of metal and allied firms is 0.398 and a p-value of 0.003 . This means that the correlation is positive and significant implying that increase in practices on supplier's technical capability will lead to increase in performance of metal and allied firms. The results are consistent with Harnowo (2015) findings on his study which focused on the influence of technology in supply chain performance and revealed that technology incorporated by suppliers in delivering supplies to firms contributed to production levels which then determined the supply technology a firm adapts to meets its customers demand. The results of correlation analysis finally indicate that the correlation between supplier's level of human competence and performance of metal and allied firms is 0.335 and a p-value of 0.009 . This means that the correlation is positive and significant implying that increase in practices on supplier's level of human competence will lead to increase in performance of metal and allied firms. The findings concurs with Kivite (2015) findings which revealed a positive and significant relationship between supplier competency and performance amongst manufacturing firms. 
International Journal of Supply Chain and Logistics

ISSN 2520-3983 (Online)

Vol. 2, Issue 1, pp $93-117,2018$

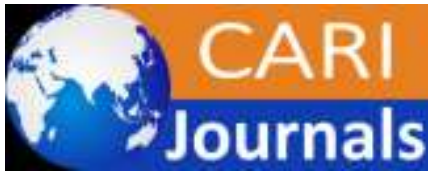

www.carijournals.org

Table 8: Correlation Analysis

$\begin{array}{lllll}\text { Financial } & \text { Regulatory } & \text { Technical } & \text { Level of HR } \\ \text { Capability } & \text { Compliance } & \text { Capability } & \text { Competence } & \text { ermanc }\end{array}$

\begin{tabular}{|c|c|c|c|c|c|c|}
\hline \multirow[t]{2}{*}{$\begin{array}{l}\text { Financial } \\
\text { Capability }\end{array}$} & $\begin{array}{l}\text { Pearson } \\
\text { Correlatio } \\
\mathrm{n}\end{array}$ & 1 & & & & \\
\hline & \multicolumn{6}{|c|}{ Sig. (2-tailed) } \\
\hline \multirow[t]{2}{*}{$\begin{array}{l}\text { Regulatory } \\
\text { Compliance }\end{array}$} & $\begin{array}{l}\text { Pearson } \\
\text { Correlatio } \\
n\end{array}$ & 0.149 & 1 & & & \\
\hline & $\begin{array}{l}\text { Sig. } \\
\text { tailed) }\end{array}$ & 0.282 & & & & \\
\hline \multirow[t]{2}{*}{$\begin{array}{l}\text { Technical } \\
\text { Capability }\end{array}$} & $\begin{array}{l}\text { Pearson } \\
\text { Correlatio } \\
\mathrm{n}\end{array}$ & 0.009 & 0.179 & 1 & & \\
\hline & $\begin{array}{l}\text { Sig. } \\
\text { tailed })\end{array}$ & 0.951 & 0.195 & & & \\
\hline \multirow[t]{2}{*}{$\begin{array}{l}\text { Level of HR } \\
\text { Competence }\end{array}$} & $\begin{array}{l}\text { Pearson } \\
\text { Correlatio } \\
\mathrm{n}\end{array}$ & 0.264 & 0.099 & $.344^{*}$ & 1 & \\
\hline & $\begin{array}{l}\text { Sig. } \\
\text { tailed })\end{array}$ & 0.054 & 0.478 & 0.011 & & \\
\hline \multirow[t]{3}{*}{ Performance } & $\begin{array}{l}\text { Pearson } \\
\text { Correlatio } \\
\mathrm{n}\end{array}$ & $.521 * *$ & $.353 * *$ & $.398 * *$ & $.335^{*}$ & 1 \\
\hline & $\begin{array}{l}\text { Sig. } \\
\text { tailed })\end{array}$ & 0 & 0.007 & 0.003 & 0.009 & \\
\hline & $\mathrm{N}$ & 146 & 146 & 146 & 146 & 146 \\
\hline
\end{tabular}


The study further conducted a multiple linear regression analysis to establish the statistical significance of the relationship between supplier evaluation (Supplier's financial capability, regulatory compliance, technical capability and level of human resource competence) and performance of metal and allied firms. The multiple linear regression was conducted at $95 \%$ confident level $(\alpha=0.05)$. The summary results of the analysis are presented in table 4.10 . The results shows a strong relationship between supplier's financial capability, regulatory compliance, technical capability and level of human resource competence and performance of metal and allied as indicated by $\mathrm{R}=.635$. The model also indicated that $\mathrm{R}$-squared which is the coefficient of determination was .586 implying that $58.6 \%$ of variation in performance of metal and allied firms can be explained by supplier's financial capability, regulatory compliance, technical capability and level of human resource competence.

Table 10: Model Summary

\begin{tabular}{llll}
\hline $\mathbf{R}$ & R Square & Adjusted R Square & Std. Error of the Estimate \\
\hline $635^{\mathrm{a}}$ & 0.586 & 0.567 & 0.2013
\end{tabular}

The ANOVA results in table 11 also indicated that the overall model linking supplier's financial capability, regulatory compliance, technical capability and level of human resource competence with performance of metal and allied firms was significant. The significance levels are confirmed by comparing the value of $F$ calculated which is 10.633 and the value of $F$ critical at $(4,141)$ which is 2.4472. The value of F calculated (10.633) is greater than the value of $F$ critical (2.4472) implying that the overall model is statistically significant.

Table 11: ANOVA (Model Significance)

\begin{tabular}{llllll}
\hline & Sum of Squares & df & Mean Square & F & Sig. \\
\hline Regression & 3.877 & 4 & 0.969 & 10.633 & 0 \\
Residual & 4.467 & 141 & 0.091 & & \\
Total & 8.344 & 145 & & & \\
\hline
\end{tabular}

Table 12 presents the results of the model coefficients. The model coefficient shows that supplier's financial capability had a positive and significant effect on performance of metal and allied firms as shown by $\beta=0.305$ and $\mathrm{Sig}=0.001<0.05$. This implies that a unit change in practices on supplier's financial capability results to an increase of 0.305 units on performance of metal and allied firms. The results are consistent with Vorster (2010) findings in her study on determinants of supplier evaluation in Pakistan Telecom industry who revealed that supplier financial capacity is one of the key factors which determine the eventual performance of both the firm and supplier. 
The model coefficient also indicates that supplier's regulatory compliance had a positive and significant effect on performance of metal and allied firms as shown by $\beta=0.241$ and Sig $=$ $0.000<0.05$.

This implies that a unit change in practices on supplier's regulatory compliance results to an increase of 0.241 units on performance of metal and allied firms. The results concurs with Mungai (2014) who revealed that that the criterion used during supplier evaluation and selection determines the comprehensive suitability of the right suppliers who can help the purchasing firm achieve competitive advantage.

The model coefficient further indicates that supplier's technical capability had a positive and significant effect on performance of metal and allied firms as shown by $\beta=0.186$ and Sig $=$ $0.000<0.05$. This implies that a unit change in practices on supplier's technical capability results to an increase of 0.186 units on performance of metal and allied firms. The results are with with Harnowo (2015) findings on his study which focused on the influence of technology in supply chain performance and revealed a positive and significant relationship between technology uptake by firms and supply chain performance. The model coefficient finally indicates that supplier's level of human resource compliance had a positive and significant effect on performance of metal and allied firms as shown by $\beta=0.229$ and Sig $=0.021<0.05$. This implies that a unit change in practices on supplier's level of human resource competence results to an increase of 0.229 units on performance of metal and allied firms. The results concurs with Kivite (2015) findings on his study to establish the effect of supplier development on performance of large manufacturing firms in Kenya which revealed a significant relationship between supplier's competency and performance of large manufacturing firms.

Table 12: Model Coefficients

\begin{tabular}{llllll}
\hline & \multicolumn{2}{l}{ Unstandardized Coefficients } & \multicolumn{3}{l}{ Standardized Coefficients } \\
\hline Predictors & B & Std. Error & Beta & t & Sig. \\
\hline (Constant) & 0.197 & 0.435 & & 0.452 & 0.653 \\
Financial Capability & 0.305 & 0.089 & 0.285 & 3.425 & 0.001 \\
Regulatory Compliance & 0.241 & 0.044 & 0.454 & 5.434 & 0.000 \\
Technical Capability & 0.186 & 0.039 & 0.385 & 4.722 & 0.000 \\
Level of HR Competence & 0.229 & 0.097 & 0.202 & 2.37 & 0.021 \\
\hline
\end{tabular}

The optimal linear regression model for the study therefore becomes:

Performance of Metal and allied firms $=0.197+0.305$ (Supplier's Financial Capability) + 0.241 (Supplier's Regulatory Compliance) + 0.229 (Supplier's Level of HR Competence) + 0.186 (Supplier's Technical Capability) 
The results according to the model indicate that Supplier's regulatory compliance and supplier's technical capability were the most significant variable followed by supplier's financial capability and lastly supplier's level of human competence. However, supplier's financial capability, regulatory compliance, technical capability and level of human resource competence positively and significantly influenced performance of metal and allied firms in Kenya.

\section{CONCLUSIONS AND RECOMMENDATIONS}

\section{Conclusions}

The study findings concluded that supplier's financial capability positively and significantly influence performance of metal and allied firms in Kenya. The study further established that practices such as evaluating supplier's balance sheets before business engagements, evaluating supplier's creditors, evaluating suppliers' cash flow management, evaluating debts owned by supplier's, evaluating assets owned by suppliers to determine their financial capability, concentrating on supplier's financial capability before engaging in business with them and conducting supplier's financial capability by use of a team comprising of credible professional with procurement/finance background positively and significantly influence performance of metal and allied firms in Kenya. The study findings also concluded that supplier's regulatory compliance positively and significantly influence performance of metal and allied firms in Kenya. Remarkably, the study established that practices such as evaluating suppliers' compliance on supply regulations, evaluating suppliers' policy compliance, conducting an assessment of suppliers' products prior engaging in business with them, evaluating supplier's certifications with regulatory bodies, providing supplier with company's set supply regulations, evaluating supplier's tax compliance and considering supplier's regulatory compliance crucial before business engagements positively and significantly influence performance of metal and allied firms in Kenya.

The study findings further concluded that supplier's technical capability positively and significantly influence performance of metal and allied firms in Kenya. The study further established that practices such as evaluating supplier's technological advancement, evaluating supplier's digitalization in supply process, highly advocating for suppliers advancement in technology, evaluating supplier's staffs educational background, considering supplier's staffs educational background a key factor in evaluation process, assessing suppliers level of computer knowledge and evaluating technical knowledge of supply operation amongst suppliers positively and significantly influence performance of metal and allied firms in Kenya. The study findings further concluded that supplier's level of human resource competence positively and significantly influence performance of metal and allied firms in Kenya. The study also established that practices such as evaluating the extent to which supplier offers one on one training to employees, evaluating the extent to which supplier values employees training, evaluating the extent to which supplier invests resources in employees training, evaluating supplier's development initiatives to employees, evaluating supplier's motivational practices to employees, evaluating suppliers competency levels and evaluating supplier's level of experience in supply operations positively and significantly influence performance of metal and allied firms in Kenya. 


\section{Recommendations}

The study recommends that metal and allied firms should focus on supplier's financial capability since the practice leads to a positive and significant improvement on performance of the firms in Kenya. Metal and allied firms can achieve by evaluating supplier's balance sheets before business engagements, evaluating supplier's creditors, evaluating suppliers' cash flow management, evaluating debts owned by supplier's, evaluating assets owned by suppliers to determine their financial capability, concentrating on supplier's financial capability before engaging in business with them and conducting supplier's financial capability by use of a team comprising of credible professional with procurement/finance background. The study also recommends that metal and allied firms should emphasize on supplier's regulatory compliance since the practice leads to a positive and significant improvement on performance of the firms in Kenya. The firms can achieve this by evaluating suppliers' compliance on supply regulations, evaluating suppliers' policy compliance, conducting an assessment of suppliers' products prior engaging in business with them, evaluating supplier's certifications with regulatory bodies, providing supplier with company's set supply regulations, evaluating supplier's tax compliance and considering supplier's regulatory compliance crucial before business engagements.

The study further recommends that metal and allied firms should advocate for supplier's technical capability since the practice leads to a positive and significant improvement on performance of the firms in Kenya. Metal and allied firms can achieve this by evaluating supplier's technological advancement, evaluating supplier's digitalization in supply process, highly advocating for suppliers advancement in technology, evaluating supplier's staffs educational background, considering supplier's staffs educational background a key factor in evaluation process, assessing suppliers level of computer knowledge and evaluating technical knowledge of supply operation amongst suppliers. The study finally recommends that metal and allied firms should consider supplier's level of human resource competence since the practice leads to a positive and significant improvement on performance of the firms in Kenya. The firms can achieve this by evaluating the extent to which supplier offers one on one training to employees, evaluating the extent to which supplier values employees training, evaluating the extent to which supplier invests resources in employees training, evaluating supplier's development initiatives to employees, evaluating supplier's motivational practices to employees, evaluating suppliers competency levels and evaluating supplier's level of experience in supply operations.

\section{Acknowledgement}

I would like to give thanks to the Almighty for the gift of knowledge and strength that have enabled the completion of this project. I acknowledge the professional support and guidance from my university supervisor Dr. Patrick Mwangangi whose direction and positive critics were fundamental throughout the entire research. I wish to extend my special gratitude to my dear family, friends and the entire JKUAT fraternity for giving me moral support, time and resources to the accomplishment of the project. 
International Journal of Supply Chain and Logistics

ISSN 2520-3983 (Online)

Vol. 2, Issue 1, pp $93-117,2018$

\section{References}

Arsan (2011) Performance Measurement and Metrics: An Analysis of Supplier Evaluation retrieved from www.scm.ncsm.edu/scm-articles on 03th June 2018

Aseka, J. (2010). Supplier selection criteria and performance of manufacturing firms listed in the Nairobi Stock Exchange. Nairobi, Kenya: (Unpublished MBA project, University of Nairobi).

Awino Z. B. \& Gituro W. (2011). An Empirical Investigation of Supply Chain Management Best

Darren, F. (2006). Appraisal and monitoring of suppliers. UK: Chartered Institute of Purchasing and Supply.

Gordon, S. R. (2006). Supplier Evaluation: Benefits, Barriers and Best Practices. 91st Annual International Supply Management Conference. Emptoris, Inc.

Emerson, R. (1976). Social Exchange Theory. Annual Review Of Sociology, 2(1), 335-362.

Hald, K. S., \&Ellegaard, C. (2011). Supplier Evaluation Processes: the Shaping 'and Reshaping of Supplier Performance. International Journal of Operations \& Production Management, 31( 8), 888 - 910.

Isobe, T., Makino, S., \& Montgomery, D. (2008). Technological capabilities and firm performance: The case of small manufacturing firms in Japan. Asia Pacific Journal Of Management, 25(3), 413-428.

Jack. A. (2011). Financial Analysis of Suppliers. Knowledge to Knowledge.

Jens, E. \&. (2014). Strategic Supplier Evaluation Considering environmental aspects. Department of Management and Engineering Logistics Management, Linköping University

Kenya Association of Manufacturers (2018). Facts and Figures

Kiprotich Mutai, J. (2016). Effects of Supplier Evaluation on Procurement Performance of Public Universities in Kenya. International Journal Of Economics, Finance And Management Sciences, 4(3), 98-116

Kitheka, S. (2015). The Effect of Supplier Quality Management on Organizational Performance: A Survey of Supermarkets in Kakamega Town. (Masters dissertation, school of business, University of Nairobi

Krause, D., \& Scannell, T. (2012). Supplier Development Practices: Product- and Service-Based Industry Comparisons. The Journal Of Supply Chain Management, 38(2), 13-21.

Kivite, J. (2015). Supplier Development And Operational Performance Of Manufacturing Firms In Nairobi City County (Masters). University Of Nairobi.

Mogikoyo, L. (2016). Supplier Evaluation Attributes and Supply Chain Performance Of Commercial State Corporations In Kenya (Masters Dissertation, School Of Business, University Of Nairobi) 
Mungai, P. M. (2014). Influence of Supplier Evaluation on Procurement Performance in the Real Estate Industry in Kenya: A Case Study of International House Ltd. International Journal of Operations and Logistics Management, 3(3), 250-262.

Okello, J. O. \& Were, S. (2014). Influence of supply chain management practices on performance of the Nairobi Securities Exchange's listed, food manufacturing companies in Nairobi. International Journal of Social Sciences and Entrepreneurship, 1 (11), $107-$ 128.

Omanga, A . N. O (2017). Influence of Supplier Evaluation on Performance of Manufacturing Firms in Kenya: A Case of Tata Chemicals Magadi (Jomo Kenyatta University of Science and Technology)

Simons, G., Brandow, R., \& Chank, M. (2007). Technology transfer in supplier-development programs. The Journal Of Technology Transfer, 16(4), 23-28.

Sundtoft Hald, K., \& Ellegaard, C. (2011). Supplier evaluation processes: the shaping and reshaping of supplier performance. International Journal Of Operations \& Production Management, 31(8), 888-910.

Tahriri, F., Rasid, M. R., Ali, A., \& Mohd Yusuff, R. (2008). A review of supplier selection methods in manufacturing industries. Suramaree Journal of Science Technology, 15(3): 201-208.

Vonderembse, M., \& Tracey, M. (2009). The Impact of Supplier Selection Criteria and Supplier Involvement on Manufacturing Performance. The Journal Of Supply Chain Management, 35(3), 33-39.

Wong, C. W., Lai, K.-H. \& Ngai, E. W., 2009. The role of supplier operational adaptation on the performance of IT-enabled transport logistics under environmental uncertainty. International Journal of Production Economics, 12(2), 47-55 